\title{
ANALISA PENGARUH FILTER WARNA DAN DAYA LAMPU FLUORESCENT TERHADAP KELAJUAN NYAMUK
}

\author{
Gita Rahayu*, Saktioto \\ Program Studi S1 Fisika \\ Fakultas Matematika dan Ilmu Pengetahuan Alam, \\ Universitas Riau Kampus Bina Widya \\ J1. Prof. Muchtar Luthfi Pekanbaru, 28293, Indonesia \\ *E-mail korespondensi: gitarahayugeget@gmail.com
}

\begin{abstract}
Mosquitoes are insects that can cause dangerous problems to human health. Therefore, mosquitoes need to be identified based on its motion so it can stay away from human. The purpose of this research is to investigate the effect of power and color spectrum of lamp toward mosquito speed. This research used optical method based on light beam that affected mosquitobody. This research designed a radiation system inside a glass box with thickness of 0,5 cm size (30x7x20) cm. Five mosquitoes were irradiated by light from fluorescent lamp with power 11 Watt and 26 Watt that have been filtered using red, orange, yellow, green, blue and purple color plastics. The radiation process was recorded using a digital camera about 26 minutes. The recorded video was processed using Tracker program. The Tracker program analyzedthe mosquito speed based on its displacement from one to another position. The results showed that mosquito highest speed at unfiltered light, red, blue and purple colors occurred when irradiated with 26 Watt lamp while at color of orange, yellow and green occured when irradiated with 11 Watt lamp. Mosquitoes highest speed value when irradiated by orange, yellow and green are $0,632 \mathrm{~m} / \mathrm{s}, 0,693 \mathrm{~m} / \mathrm{s}$ and $0,645 \mathrm{~m} / \mathrm{s}$. Mosquitoes lowest speed value when irradiated by blue and purple light are $0,308 \mathrm{~m} / \mathrm{s}$ and $0,285 \mathrm{~m} / \mathrm{s}$. The speed of the mosquitoes when irradiated by red and unfiltered lights are $0,517 \mathrm{~m} / \mathrm{s}$ and $0,541 \mathrm{~m} / \mathrm{s}$ respectively. The data showed that mosquitoes moved away from light source when irradiated by unfiltered lights, red, blue and purple while mosquitoes approached the light source when irradiated by orange, yellow and green light.
\end{abstract}

Keywords : Mosquito, Fluorescent Lamp, Color Filter, Mosquito Speed, Lamp Power.

\begin{abstract}
ABSTRAK
Nyamuk adalah salah satu serangga yang berbahaya bagi manusia. Nyamuk perlu diidentifikasi geraknya agar menjauhi manusia. Tujuan penelitian ini adalah untuk mengetahui pengaruh daya dan warna lampu terhadap kelajuan nyamuk. Metode yang digunakan adalah metode optik berdasarkan pancaran cahaya lampu yang mengenai fisik nyamuk. Penelitian ini merancang sebuah sistem peradiasian di dalam kotak kaca dengan ketebalan 0,5 cm berukuran $30 \mathrm{~cm} \times 7 \mathrm{~cm} \times 20 \mathrm{~cm}$. Lima ekor nyamuk disinari cahaya dari lampu fluorescent dengan daya 11 Watt dan 26 Watt yang difilter menggunakan plastik warna merah, jingga, kuning, hijau, biru dan ungu. Proses radiasi direkam menggunakan kamera digital selama \pm 26 menit. Video hasil rekaman diolah menggunakan aplikasi Tracker. Aplikasi Tracker menganalisa kelajuan nyamuk berdasarkan perpindahannya dari satu posisi ke posisi lain. Hasil penelitian menunjukkan kelajuan nyamuk tertinggi dengan cahaya lampu tanpa filter, warna merah, biru dan ungu terjadi saat disinari lampu 26 Watt sedangkan untuk warna jingga, kuning dan hijau terjadi saat disinari lampu 11 Watt. Nilai kelajuan tertinggi nyamuk saat disinari oleh warna jingga, kuning dan hijau adalah 0,632 m/s, 0,693 m/s dan 0,645 m/s. Nilai kelajuan terendah nyamuk saat disinari oleh cahaya biru dan ungu adalah $0,308 \mathrm{~m} / \mathrm{s}$ dan $0,285 \mathrm{~m} / \mathrm{s}$. Kelajuan nyamuk saat disinari oleh warna merah dan lampu tanpa filter adalah $0,517 \mathrm{~m} / \mathrm{s}$ dan $0,541 \mathrm{~m} / \mathrm{s}$. Data ini menunjukkan nyamuk menjauhi sumber cahaya saat disinari cahaya lampu tanpa filter, warna merah, biru dan ungu sedangkan nyamuk mendekati sumber cahaya saat disinari cahaya lampu warna jingga, kuning dan hijau.
\end{abstract}

Kata Kunci: Nyamuk, Lampu Fluorescent, Filter Warna, Kelajuan Nyamuk, Daya Lampu.

\section{PENDAHULUAN}

Nyamuk merupakan serangga pembawa patogen berbahaya bagi manusia seperti malaria, DBD, filariasis, cikungunya dan berbagai penyakit mematikan lainnya. Pada tahun 2015 terdapat 214 juta kasus Malaria yang menyebabkan 438.000 kematian di 
seluruh dunia [1]. Beberapa Provinsi di Indonesia bahkan melaporkan Kejadian Luar Biasa (KLB) untuk penyakit Demam Berdarah Dengue pada tahun 2014 dengan total 100.347 kasus yang menyebabkan 907 orang meninggal dunia di seluruh Indonesia [2] .

Salah satu metode yang sedang dikembangkan untuk mengontrol nyamuk saat ini yaitu metode Electronic Mosquito Repellent (EMR). EMR adalah sebuah metode penangkal nyamuk yang menggunakan berbagai instrumen elektrik. Salah satu contohnya yaitu instrumen elektrik yang memancarkan gelombang ultrasonik untuk menarik nyamuk betina. Studi kasus beberapa peneliti terhadap berbagai EMR yang memancarkan gelombang ultrasonik menyimpulkan bahwa alat ini sangat tidak efektif dan tidak direkomendasikan untuk menangkal gangguan nyamuk [3].

Negara Jepang sebagai contoh saat ini tengah mengembangkan suatu metode optik untuk membasmi serangga yang merugikan dalam bidang pertanian. Penelitian ini dilakukan berdasarkan sifat responsif serangga terhadap cahaya [4].

Respon serangga terhadap cahaya sangat dipengaruhi oleh berbagai faktor seperti intensitas cahaya, panjang gelombang, lamanya serangga terpapar cahaya, arah sumber cahaya, kontras sumber cahaya dan warna cahaya serta jenis sumber cahaya yang digunakan itu sendiri.

Beberapa kegiatan serangga dipengaruhi oleh responnya terhadap cahaya. Cahaya ternyata dapat memicu berbagai macam respon dan tingkah laku serangga. Respon serangga terhadap cahaya disebut dengan Phototaxis.

Populernya metode optik untuk membasmi dan mengontrol serangga membuat para peneliti mulai mengembangkan berbagai sumber cahaya yang digunakan. Sumber cahaya yang digunakan salah satunya adalah sumber cahaya buatan. Para peneliti pun telah membuktikan bahwa nyamuk tertarik dengan cahaya yang ditransmisikan [5]. Namun hingga saat ini belum diketahui cahaya dengan karakteristik seperti apa yang dapat menangkal nyamuk.

Suksesnya metode optik berbasis gelombang elektromagnetik dalam membasmi dan mengontrol serangga melatarbelakangi penulis untuk melakukan penelitian mengenai pengaruh filter warna dan daya lampu fluorescent terhadap kelajuan nyamuk. Dalam penelitian ini nyamuk akan diradiasikan dengan cahaya lampu fluorescent. Cahaya polikromatis dari lampu nantinya akan difilter menggunakan berbagai plastik warna. Penulis akan merancang sebuah sistem untuk mengetahui bagaimana pengaruh cahaya tampak dengan daya, intensitas, suhu yang dihasilkan saat radiasi terhadap kelajuan nyamuk.

\section{KAJIAN LITERATUR}

\section{Cahaya}

Cahaya adalah radiasi gelombang elektromagnetik yang mempunyai frekuensi dan panjang gelombang tertentu sehingga dapat dilihat oleh mata manusia.

Cahaya adalah salah satu bagian dari spektrum gelombang elektromagnetik (Gambar 1). Panjang gelombang dari cahaya tampak mulai dari $380 \mathrm{~nm}$ dengan warna ungu-biru sampai dengan $750 \mathrm{~nm}$ untuk warna merah pekat. Warna biru murni terletak pada panjang gelombang $475 \mathrm{~nm}$, warna hijau sekitar $520 \mathrm{~nm}$, warna kuning sekitar $575 \mathrm{~nm}$ dan warna merah $630 \mathrm{~nm}$. Panjang gelombang di bawah $380 \mathrm{~nm}$ adalah sinar Ultraviolet dan di atas 750 adalah sinar Infrared.

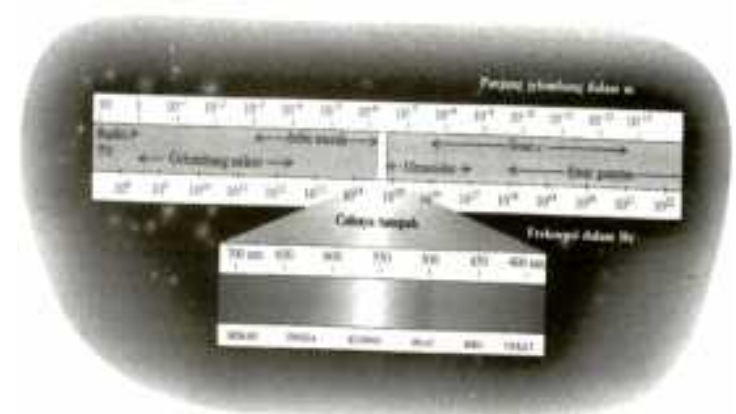

Gambar 1. Spektrum gelombang elektromagnetik [6]. 


\section{Lampu Fluorescent Sebagai Sumber Cahaya}

Lampu tabung Fluorescent terdiri dari gelas kaca dimana dinding bagian dalam dilapisi dengan serbuk Fosfor yang pada dasarnya merupakan material semikonduktor dengan tambahan zat pengaktif lain untuk mengubah radiasi ultraviolet menjadi cahaya tampak[7]. Keungulan dan kelemahan lampu fluorescent diberikan pada Tabel 1.

Tabel 1. Kelebihan dan Kelemahan Lampu Fluorescent [8].

\begin{tabular}{|c|c|}
\hline Kelebihan & Kelemahan \\
\hline $\begin{array}{l}\text { - } \\
\text { fikasi yang baik } \\
- \\
\text { aktu hidup panjang } \\
\text { (6000-9000 jam) } \\
\text { - } \\
\text { ingkat intensitas } \\
\text { cahaya rendah } \\
- \\
\text { emperatur operasi } \\
\text { rendah } \\
- \\
\text { erformansi warna } \\
\text { baik (warna cahaya } \\
\text { berbeda-beda) } \\
\text { - } \\
\text { inar tampak dengan } \\
\text { spektrum lebih } \\
\text { lebar } \\
\text { - } \\
\text { apat dioperasikan } \\
\text { pada tegangan } \\
\text { sistem yang lebih } \\
\text { tinggi } \\
\text { - } \\
\text { enundaan starting } \\
\text { dan restarting hanya } \\
\text { sesaat }\end{array}$ & $\begin{array}{l}\text { - } \\
\text { ukan merupakan } \\
\text { sumber cahaya titik } \\
\text { sehingga distribusi } \\
\text { cahaya lebih sulit } \\
\text { dikendalikan } \\
\text { - } \\
\text { embutuhkan } \\
\text { peralatan tambahan } \\
\text { sebagai kontrol } \\
\text { lampu } \\
\text { - } \\
\text { angat dipengaruhi } \\
\text { oleh temperatur } \\
\text { lingkungan } \\
\text { - } \\
\text { utuh pengontrol } \\
\text { khusus } \\
\text { mengatur intensitas } \\
\text { cahaya } \\
\text { - } \\
\text { kuran lebih besar }\end{array}$ \\
\hline
\end{tabular}

Lampu Fluorescent di dalamnya diisi dengan gas inert berupa argon atau kripton yang berfungsi untuk penyalaan awal dan uap air raksa (merkuri) yang akan mengubah $60 \%$ dari daya input. Fungsi lain dari gas inert adalah memperpanjang umur elektroda karena keberadaan gas tersebut mengurangi evaporasi pengendali kelajuan lintasan elektron bebas sehingga lebih memungkinkan terjadinya ionisasi merkuri dan mempermudah lewatnya arus di dalam tabung khususnya pada temperatur rendah [9].

\section{Interaksi Serangga Terhadap Cahaya}

Beberapa kegiatan serangga dipengaruhi oleh responnya terhadap cahaya. Ada serangga yang aktif pada siang hari dan ada juga serangga yang aktif pada malam hari. Serangga yang aktif pada siang hari disebut serangga diurnal sedangkan serangga yang aktif pada malam hari disebut serangga nocturnal.

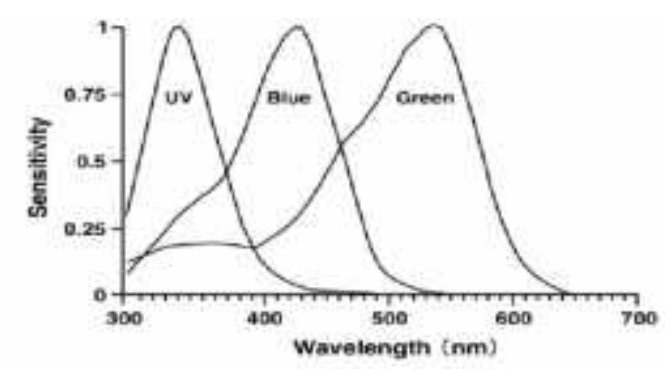

Gambar 2. Kurva kepekaan warna tiga tipe sel photoreceptor dari lebah madu (Apis Mellifera). Spektrum di atas kurva adalah spektrum cahaya tampak yang dapat dilihat manusia [10].

Serangga mampu melihat radiasi sinar ultraviolet (UV) karena serangga mempunyai mata faset (majemuk) dan mata tunggal (ocellus) [4]. Mata faset mempunyai ukuran lebih besar daripada mata tunggal. Mata faset mampu menerima sinar yang sudut datangnya lebih besar dari $180^{\circ}$. Menurut [4] mata faset memiliki banyak unit yang sensitif terhadap cahaya disebut ommatidia. Sebuah ommatidia mengadung kumpulan panjang sel photoreceptor yang peka terhadap warna tertentu pada masing-masing selnya. Photoreceptor yang peka terhadap warna berperan dalam menentukan panjang 
gelombang cahaya tampak yang akan dilihat oleh serangga dan penglihatannya diperluas hingga daerah sinar UV yang tidak mampu dilihat oleh manusia. Mata faset mengandung tiga tipe sel photoreceptor yang peka terhadap sinar UV, warna biru dan warna hijau seperti yang dimiliki oleh lebah madu (Apis Mellifera) seperti yang terlihat pada Gambar 2. Rata-rata serangga menganggap sinar UV sebagai warna yang unik. Sensitivitas photoreceptor pada sinar UV, warna biru dan hijau pada genus Apis mirip dengan rata-rata seluruh serangga seperti nyamuk contohnya.

Cahaya dapat mempengaruhi berbagai macam tingkah laku serangga yang dapat dikelompokkan menjadi beberapa kategori seperti yang terlihat pada Gambar 3. Pertama yaitu ketertarikan serangga terhadap sumber cahaya. Hal ini disebut dengan Phototaxis Positif dimana serangga akan mendekat ke arah sumber cahaya. Tingkah laku ini dimanfaatkan untuk membuat perangkap serangga dengan syarat sumber cahaya memiliki panjang gelombang serta intensitas yang efektif. Kedua yaitu penolakan terhadap cahaya. Hal ini disebut juga dengan phototaxis negatif dimana serangga akan menjauhi sumber cahaya. Tingkah laku ini dimanfaatkan untuk menangkal serangga memasuki daerah yang ingin dilindungi.

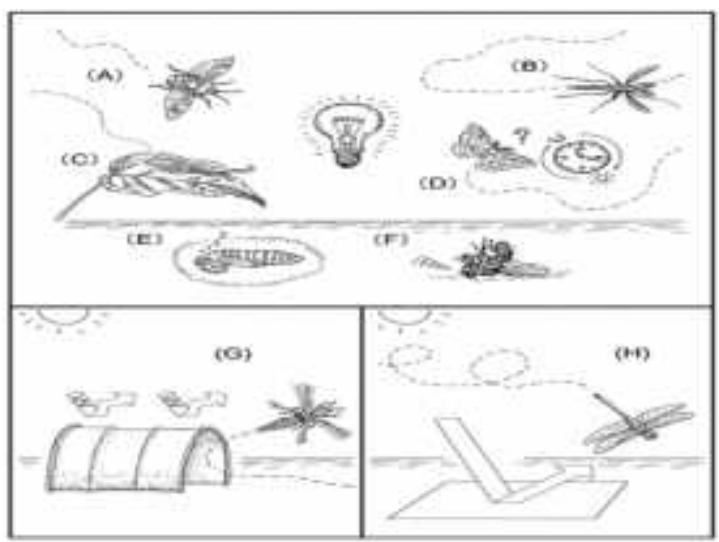

Gambar 3 Berbagai macam respon serangga terhadap cahaya. (A) Phototaxis Positif. (B) Phototaxis negatif. (C) Adaptasi cahaya. (D) Kebingungan dengan waktu. (E) Photoperiodicity. (F) Keracunan cahaya. (G) Kontrol Penglihatan. (H) Reaksi terhadap cahaya pantul [4].
Pertama yaitu ketertarikan serangga terhadap sumber cahaya. Hal ini disebut dengan Phototaxis Positif dimana serangga akan mendekat ke arah sumber cahaya. Tingkah laku ini dimanfaatkan untuk membuat perangkap serangga dengan syarat sumber cahaya memiliki panjang gelombang serta intensitas yang efektif. Kedua yaitu penolakan terhadap cahaya. Hal ini disebut juga dengan phototaxis negatif dimana serangga akan menjauhi sumber cahaya. Tingkah laku ini dimanfaatkan untuk menangkal serangga memasuki daerah yang ingin dilindungi. Selanjutnya ketiga yaitu adaptasi terhadap cahaya. Serangga nocturnal yang terpapar cahaya buatan pada malam hari akan beradaptasi dengan sumber cahaya buatan. Para peneliti melakukan jeda selama peradiasian untuk menghindari hal ini.

Respon keempat yaitu gangguan jadwal yang mengakibatkan kebingungan membedakan antara siang dan malam sehingga tingkah laku serangga diurnal maupun nocturnal akan berganti sesuai kebiasaan pada waktu sebenarnya. Respon kelima yaitu photoperiodicity. Photoperiodicity adalah respon psikologis serangga terhadap musim serta jadwal cahaya yang mengakibatkan serangga tidak akan bertahan melewati musim dingin karena tidak dapat berhibernasi. Respon keenam yaitu keracunan cahaya. Mata faset pada serangga dapat keracunan sinar UV dan warna biru akibat radiasi yang berlebihan. Namun ada beberapa serangga yang mampu bertahan serta menyembuhkan diri.

Respon selanjutnya yaitu dengan cara menghalangi masuknya sinar UV ke dalam sebuah tempat. Hal ini menyebabkan serangga tidak mampu melihat apapun yang berada di dalam tempat yang tidak ada sinar UV dan pergi menjauh. Terakhir yaitu memantulkan cahaya dari tanah sehingga serangga menganggap cahaya pantul tersebut adalah cahaya matahari yang berada di balik punggungnya. Semua respon serangga terhadap cahaya dipengaruhi oleh beberapa 
faktor seperti intensitas, panjang gelombang, waktu paparan serta jenis sumber cahaya.

\section{Karakteristik Fisis Nyamuk}

Nyamuk merupakan serangga yang termasuk dalam filum arthropoda klas insekta ordo diptera famili culicidae. Nyamuk mempunyai beberapa ciri yaitu tubuhnya dibedakan atas tiga bagian yaitu bagian kepala (kaput), dada (thoraks) dan perut (abdomen). Bentuk kepala nyamuk hampir bulat dan memiliki susunan mata yang besar. Nyamuk mempunyai lima bagian anggota tubuh yaitu dua buah antena, dua palpi dan dua proboscis. Bagian dada (thoraks) terbagi atas tiga bagian yaitu prothoraks, mesothoraks dan metathoraks. Masing-masing bagian memiliki sepasang kaki. Pada bagian mesothoraks terdapat sepasang sayap. Pada bagian metathoraks terdapat bagian yang menonjol mirip sepasang sayap yang disebut dengan halteres. Nyamuk mengalami metamorfosis sempurna mulai dari telur, larva, pupa hingga nyamuk dewasa, lihat Gambar 4.

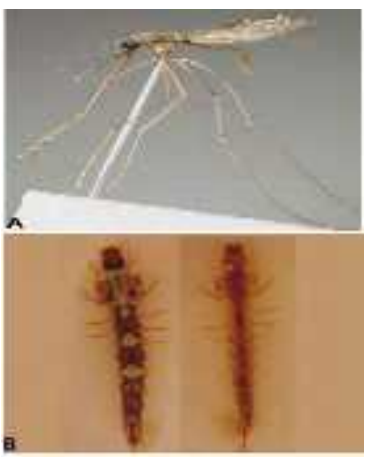

(A)
(B)

Gambar 4. (A) Nyamuk betina dewasa, Anopheles sinensis. (B) Larva nyamuk [11].

Nyamuk menggunakan rangsangan visual, termal dan penciuman untuk melacak mangsanya [11]. Penciuman nyamuk berperan penting dalam menemukan mangsa dengan tepat sedangkan indra penglihatan nyamuk digunakan untuk mengontrol pergerakan saat terbang. Jarak terbang nyamuk Ae. aegypti betina rata-rata 40-100 meter dari tempat perindukannya [12].
[12] juga menjelaskan bahwa suhu udara sangat berpengaruh bagi perkembangan nyamuk serta virus maupun bakteri yang dibawanya. Nyamuk dapat hidup pada suhu rendah dengan konsekuensi turunnya metabolisme nyamuk bahkan akan berhenti apabila suhu turun hingga titik kritis. Begitu juga sebaliknya fisiologi nyamuk akan melambat bila suhu lingkungan lebih dari $35^{\circ} \mathrm{C}$. Hal ini disebabkan karena terjadi denaturasi protein dalam tubuh nyamuk sehingga mengganggu keseimbangan proses metabolisme. Hal ini menyebabkan timbul sisa-sisa metabolisme yang berubah menjadi racun sehingga mengurangi mobilitas nyamuk. Rata-rata suhu optimal untuk nyamuk adalah $25^{\circ} \mathrm{C}-27^{\circ} \mathrm{C}$. Pertumbuhan nyamuk akan benarbenar berhenti bila suhu lebih tinggi dari $40^{\circ} \mathrm{C}$ atau lebih rendah dari $10^{\circ} \mathrm{C}$.

\section{METODE PENELITIAN}

Gambar 5 dan 6 merupakan rancangan skema dan diagram alir penelitian skala laboratorium untuk mengetahui pengaruh radiasi cahaya tampak terhadap nyamuk ini. Terdapat dua jenis kotak dalam sistem ini yaitu kotak kaca dan kotak karton. Kotak kaca berfungsi sebagai wadah peradiasian sampel menggunakan cahaya tampak yang bersumber dari lampu dengan suhu warna normal yang warnanya hampir sama dengan cahaya pada siang hari (daylight color) dengan tujuan memudahkan koreksi warna dengan berbagai panjang gelombang menggunakan plastik warna-warni. Kotak kaca dirancang dengan lebar yang kecil sebesar $8 \mathrm{~cm}$ sehingga kotak kaca dianggap 2D apabila dipandang dari depan untuk memudahkan menghitung pergerakan serta kelajuan perpindahan nyamuk.

Langkah awal dari penelitian ini adalah mengontrol sampel untuk meminimalisir kemungkinan error yang berasal dari nyamuk sehingga data yang didapatkan sesuai dengan tujuan awal penelitian. Semua alat dan bahan yang telah dipersiapkan dirancang sesuai sistem yang telah direncanakan sesuai dengan 
Gambar 5 bersamaan dengan persiapan nyamuk.

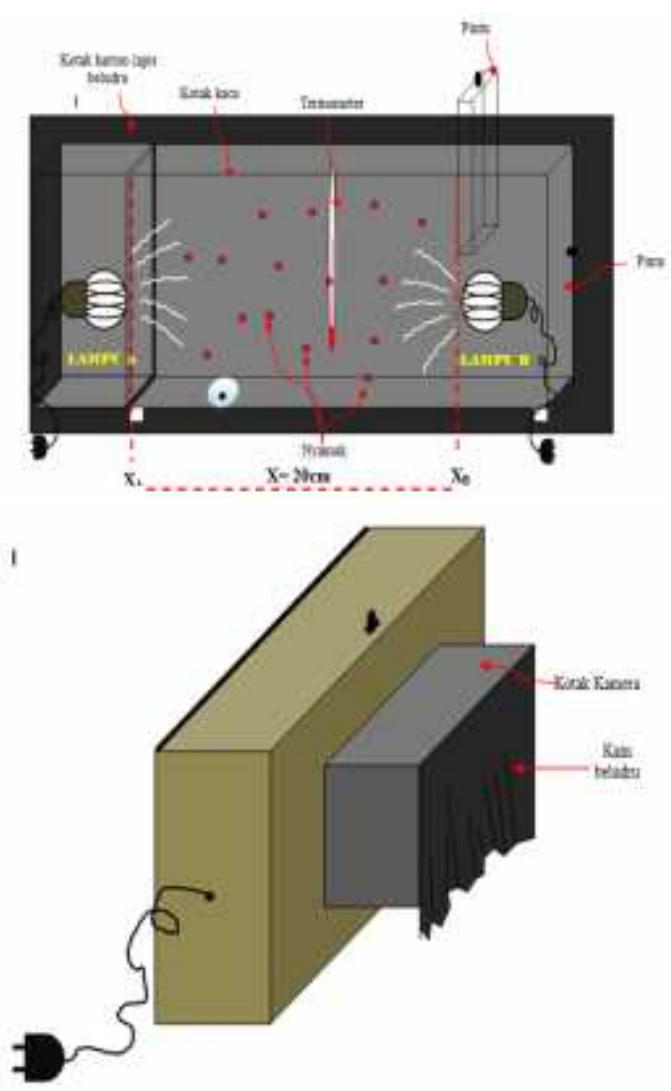

Gambar 5. Skema penelitian.

Langkah kedua yaitu meradiasikan nyamuk dengan masing-masing lampu $11 \mathrm{~W}$ dan $26 \mathrm{~W}$ selama \pm 26 menit. Suhu dan intensitas cahaya dicatat setiap rentang 5 menit. Proses peradiasian direkam menggunakan kamera digital dari awal hingga akhir. Setelah 26 menit lampu dimatikan. Video hasil rekaman dipindahkan dan disimpan ke laptop. Nyamuk dibiarkan beristirahat lagi selama kurang lebih 15 menit dan suhu di dalam kotak dibiarkan turun kembali hingga menyamai suhu ruangan. Filter warna ditukar dengan filter warna selanjutnya selama nyamuk beristirahat dan dilanjutkan sama seperti langkah sebelumnya.

Langkah-langkah yang dilakukan pun sama untuk masing-masing daya lampu hanya saja lampu di posisi B tidak diberi filter dan hanya menggunakan warna daylight saja. Setelah peradiasian semua nyamuk dimusnahkan agar tidak menyebarkan penyakit dan dianalisa menggunakan aplikasi Tracker, lihat Gambar 7.

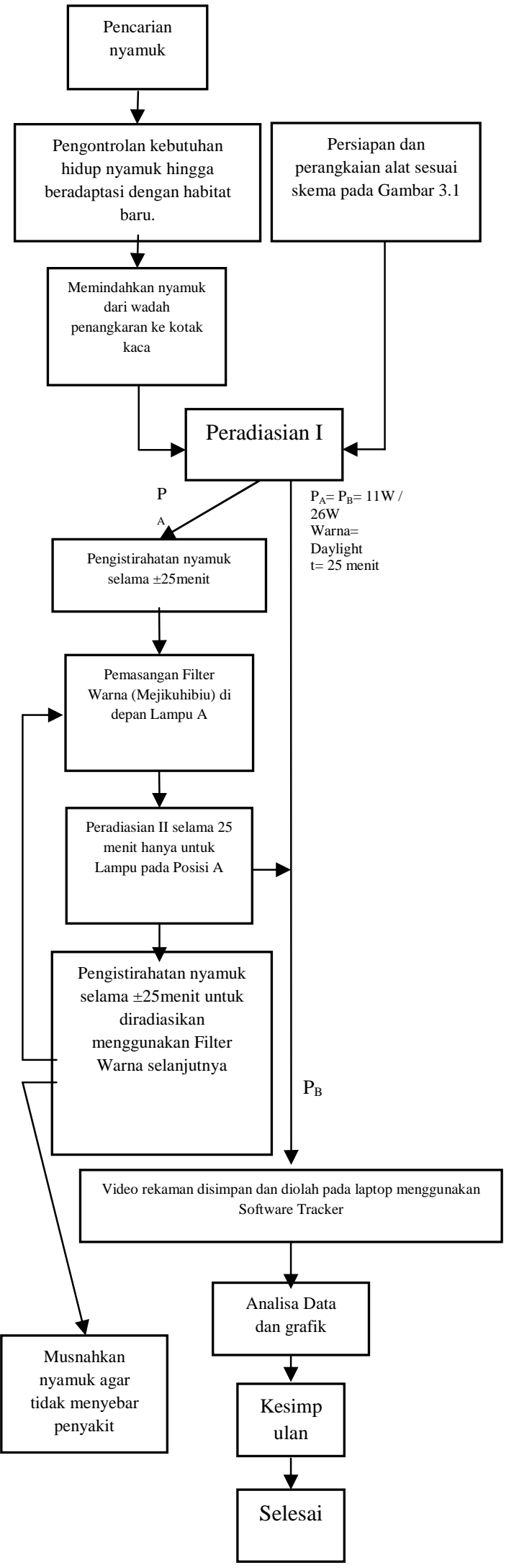

Gambar 6. Diagram Alir Penelitian. 
Sebelum video diolah, ada beberapa hal yang harus diatur untuk mendapatkan hasil yang akurat. Pertama video harus dikalibrasi menggunakan benda yang memiliki ukuran asli di dunia nyata. Benda yang digunakan dalam penelitian ini adalah lidi berukuran 0.1 meter. Benda acuan harus masuk dalam rekaman. Hal ini bermaksud agar data yang nantinya dihasilkan akan sesuai dengan satuan di dunia nyata.

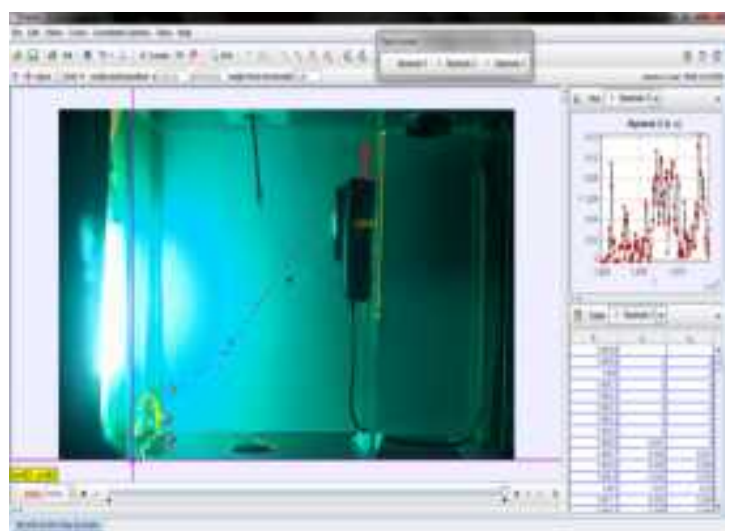

Gambar 7. Tampilan Software Tracker.

Kedua sumbu koordinat $\mathrm{x}$ dan $\mathrm{y}$ dimasukkan pada video. Koordinat $(0,0)$ diletakkan pas dengan pojok kiri bawah kotak kaca. Hal ini bertujuan agar data lintasan terbang nyamuk dapat dianalisa lebih akurat.

Ketiga atur karakteristik video dengan cara membuka clip settings pada aplikasi Tracker. Video dengan ukuran yang lebih kecil memiliki kekurangan berupa gambar yang tidak jernih dan pecah-pecah sehingga sangat menyulitkan ketika menganalisa lintasan nyamuk. Video pun diatur agar memiliki kelajuan antar frame sebesar $25 \mathrm{fps}$ dengan waktu antar frame 0,04 detik sehingga memudahkan pengolahan data.

Video yang sudah dikonversi dan dikalibrasi diolah menggunakan software Tracker untuk menganalisa kelajuan serta pergerakan nyamuk pada sumbu $\mathrm{x}$ dan sumbu $y$ yang dihitung berdasarkan perpindahan nyamuk antar frame video. Tampilan aplikasi Tracker. Aplikasi ini akan memberikan hasil berupa grafik serta tabel data berbagai variabel fisis yang diinginkan.

\section{HASIL DAN PEMBAHASAN}

\section{Pengelolaan Nyamuk Sebagai Sampel Penelitian}

Penelitian ini menggunakan nyamuk sebagai sampel utama. Kenyataannya sangat sulit untuk menemukan nyamuk siap teliti dengan jenis yang seragam. Hal ini dapat diatasi dengan cara mengambil jentik nyamuk dari tempat yang sama dengan asumsi memperbesar kemungkinan mendapatkan jenis nyamuk seragam yang hidup dalam habitat yang sama. Namun, butuh penelitian lebih lanjut untuk menentukan jenis pasti nyamuk yang didapat. Penelitian pun dilanjutkan tanpa mengetahui jenis nyamuk yang menjadi sampel utama dengan pertimbangan penelitian dianggap serupa dengan kehidupan sehari-hari dimana berbagai jenis nyamuk berkeliaran di sekitar manusia.

\section{Pengaruh Suhu Terhadap Respon Nyamuk}

Pada penelitian ini digunakan dua lampu dengan daya 11 watt dan 26 watt yang difilter menggunakan enam plastik warna merah, jingga, kuning, hijau, biru, ungu dan warna bawaan lampu. Intensitas cahaya lampu hanya diukur di titik terjauh dari lampu sementara suhu diukur di sembilan titik dengan jarak seperti terlihat pada Tabel 2. Tujuan pengukuran suhu di sembilan titik adalah untuk mengetahui sebaran suhu di masingmasing titik.

Tabel 2. Titik pengukuran suhu

\begin{tabular}{|r|c|c|}
\hline Titik & $\begin{array}{c}\text { Jarak } \\
\text { Termometer } \\
\text { Dasar Wadah }\end{array}$ & $\begin{array}{c}\text { Jarak } \\
\text { Termometer - } \\
\text { Lampu }\end{array}$ \\
\hline 1 & $0,5 \mathrm{~cm}$ & \\
2 & $10 \mathrm{~cm}$ & $2,5 \mathrm{~cm}$ \\
3 & $19,5 \mathrm{~cm}$ & \\
\hline 4 & $0,5 \mathrm{~cm}$ & \\
5 & $10 \mathrm{~cm}$ & $12 \mathrm{~cm}$ \\
6 & $19,5 \mathrm{~cm}$ & \\
\hline 7 & $0,5 \mathrm{~cm}$ & \\
8 & $10 \mathrm{~cm}$ & $19,5 \mathrm{~cm}$ \\
9 & $19,5 \mathrm{~cm}$ & \\
\hline
\end{tabular}


Menurut [11] Nyamuk menggunakan rangsangan visual, termal dan penciuman untuk melacak mangsanya. Nyamuk membentuk lintasan saat terbang yang bervariasi. Untuk semua filter warna, nyamuk rata-rata sering melalui titik 7 yang berada di posisi paling bawah kotak kaca yang terletak paling jauh dari sumber cahaya. Namun dari pengukuran suhu yang dilakukan tidak terlihat perbedaan suhu yang berarti daripada titik-titik lainnya.

Pola suhu ini terjadi akibat salah satu dari kelemahan lampu fluorescent yang dirumuskan oleh [8] dimana suhu yang dihasilkan lampu sangat dipengaruhi oleh suhu lingkungan saat pengukuran. Hal ini menunjukkan bahwa suhu lingkungan ikut terukur pada saat peradiasian membuat data pengukuran menjadi tak terpola ditiap titiknya saat data diambil pada waktu yang berbeda. Oleh karena itu respon nyamuk terhadap perubahan suhu ditiap titik tidak dapat disimpulkan akibat pengambilan data yang tidak akurat.

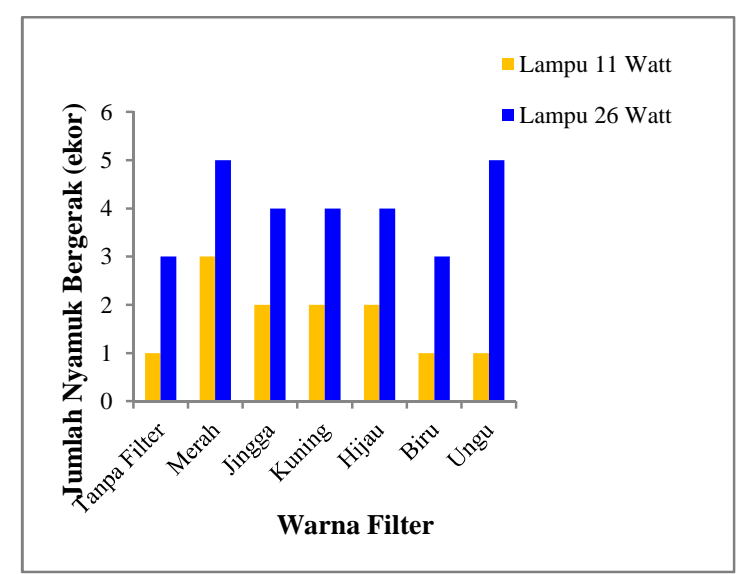

Gambar 8. Grafik jumlah nyamuk yang bergerak saat peradiasian.

Meskipun pengaruh suhu ditiap titik terhadap respon nyamuk tidak dapat disimpulkan namun lintasan terbang nyamuk selama peradiasian menunjukkan suatu pola terhadap perubahan suhu di dalam kotak kaca secara keseluruhan. Menurut [12] rata-rata suhu optimal untuk nyamuk adalah $25^{\circ} \mathrm{C}$ $27^{\circ} \mathrm{C}$ dan nyamuk tidak dapat hidup optimal apabila suhu lebih rendah dari $10^{\circ} \mathrm{C}$ atau lebih tinggi dari $40^{\circ} \mathrm{C}$. Hal ini terlihat dalam pola pergerakkan nyamuk dimana nyamuk bergerak semakin agresif saat suhu dalam kotak kaca semakin tinggi seiring waktu. Gambar 8 menunjukkan grafik jumlah nyamuk yang bergerak saat peradiasian.

Kesimpulannya adalah respon nyamuk terhadap suhu di tiap titik tidak dapat diketahui karena perubahan suhu tidak signifikan namun perubahan suhu secara keseluruhan di dalam kotak kaca membuat nyamuk bergerak semakin aktif seiring meningkatnya suhu dalam kotak kaca.

\section{Pengaruh Filter Warna Dan Daya Lampu Fluorescent Terhadap Kelajuan Nyamuk}

Filter warna digunakan untuk memisahkan cahaya agar meneruskan satu panjang gelombang tertentu yang diinginkan. Penelitian ini menggunakan plastik warna merah, jingga, kuning, hijau, biru dan ungu sebagai filter cahaya. Plastik warna awalnya diukur menggunakan spektometer untuk mengetahui panjang gelombangnya. Namun hasil dari grafik menunjukkan bahwa lampu tanpa filter, warna merah, jingga, kuning dan hijau mempunyai panjang gelombang yang hampir sama yaitu $612 \mathrm{~nm}$. Hal ini terjadi karena penelitian ini hanya menggunakan plastik warna biasa. Untuk penelitian selanjutnya mungkin dapat menggunakan filter warna yang lebih bagus agar hasilnya lebih akurat. Tetapi tidak jadi masalah karena warna yang dihasilkan cukup jelas untuk divisualisasikan oleh manusia maupun mata nyamuk yang selanjutnya dapat mempengaruhi pergerakkan nyamuk.

Kelajuan nyamuk diperoleh dari hasil analisa menggunakan aplikasi Tracker dimana kelajuan dihitung berdasarkan perpindahan nyamuk dari satu posisi ke posisi lain antar frame. Kelajuan nyamuk dianalisa hanya pada saat nyamuk terbang dari satu titik ke titik lain. Nyamuk yang berjalan pelan atau tidak terbang kelajuannya dianggap nol. Hal ini bermaksud untuk mempersempit jumlah data dan menghemat waktu agar mendapatkan hasil 
yang maksimal karena data yang diolah menggunakan aplikasi Tracker berjumlah sangat banyak. Satu video dapat menghasilkan paling sedikit 10.000 data dan maksimal 40.000 buah data tergantung frame video yang diatur pada saat awal sebelum mengolah video.

Gambar 9 menunjukkan bahwa nilai kelajuan tertinggi nyamuk saat disinari oleh warna jingga, kuning dan hijau adalah 0,632 $\mathrm{m} / \mathrm{s}, 0,693 \mathrm{~m} / \mathrm{s}$ dan $0,645 \mathrm{~m} / \mathrm{s}$. Nilai kelajuan terendah nyamuk saat disinari oleh cahaya biru dan ungu adalah $0,308 \mathrm{~m} / \mathrm{s}$ dan $0,285 \mathrm{~m} / \mathrm{s}$. Kelajuan nyamuk saat disinari oleh warna merah dan lampu tanpa filter adalah $0,517 \mathrm{~m} / \mathrm{s}$ dan $0,541 \mathrm{~m} / \mathrm{s}$.

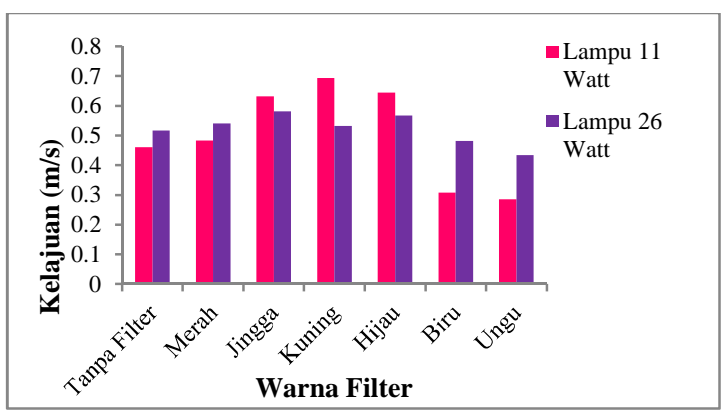

Gambar 9. Grafik perbandingan kelajuan nyamuk terhadap fillter warna.

Tabel 3. Kelajuan Nyamuk Berdasarkan Filter Warna.

\begin{tabular}{|c|c|c|}
\hline \multirow{2}{*}{$\begin{array}{c}\text { Filter } \\
\text { Warna }\end{array}$} & \multicolumn{2}{|c|}{ Kelajuan Nyamuk (m/s) } \\
\cline { 2 - 3 } & $\begin{array}{c}\text { Lampu } \\
\text { 11 Watt }\end{array}$ & $\begin{array}{c}\text { Lampu } \\
\text { 26 Watt }\end{array}$ \\
\hline $\begin{array}{c}\text { Tanpa } \\
\text { Filter }\end{array}$ & 0,461 & 0,517 \\
Merah & 0,483 & 0,541 \\
Jingga & 0,632 & 0,581 \\
Kuning & 0,693 & 0,532 \\
Hijau & 0,645 & 0,567 \\
Biru & 0,308 & 0,482 \\
Ungu & 0,285 & 0,434 \\
\hline
\end{tabular}

Daya lampu pun sangat mempengaruhi kelajuan nyamuk seperti yang terlihat pada grafik dimana nyamuk rata-rata bergerak cepat saat disinari lampu berdaya 26 watt. Pada daya 26 watt hanya terjadi perbedaan pada warna jingga, kuning dan hijau dimana kelajuan nyamuk lebih tinggi pada daya 11 watt daripada daya 26 watt. Perbedaan kelajuan nyamuk dapat dilihat dalam Tabel 3. Hal ini menunjukkan bahwa nyamuk menjadi sangat aktif saat disinari oleh cahaya berwarna jingga, kuning dan hijau yang ditunjukkan dengan kelajuan terbang yang tinggi.

Selain kelajuan yang tinggi, ternyata nyamuk menunjukkan respon bila diradiasi dengan warna tertentu. Dalam Lampiran 3 dapat dilihat bahwa nyamuk yang diradiasi oleh lampu warna jingga, kuning dan hijau cenderung lebih sering bergerak mendekati cahaya. Sementara nyamuk yang diradiasi oleh lampu tanpa filter, warna merah, biru dan ungu cenderung bergerak menjauhi cahaya dan acap kali bergerak dan diam di titik 7 .

\section{KESIMPULAN}

Nyamuk bergerak dengan kelajuan tertinggi saat disinari oleh warna jingga, kuning dan hijau dan bergerak dengan kelajuan rendah saat disinari cahaya biru dan ungu. Kelajuan nyamuk tertinggi dengan cahaya lampu tanpa filter, warna merah, biru dan ungu terjadi saat disinari lampu 26 Watt sedangkan untuk warna jingga, kuning dan hijau terjadi saat disinari lampu 11 Watt. Respon nyamuk terhadap suhu di tiap titik tidak dapat diketahui karena perubahan suhu tidak signifikan namun perubahan suhu secara keseluruhan di dalam kotak kaca membuat nyamuk bergerak semakin aktif seiring meningkatnya suhu dalam kotak kaca. Nyamuk yang diradiasi oleh lampu warna jingga, kuning dan hijau cenderung bergerak mendekati cahaya sementara nyamuk yang diradiasi oleh lampu tanpa filter, warna merah, biru dan ungu cenderung bergerak menjauhi cahaya.

\section{REFERENSI}

1. World Health Organization. (2015). World Malaria Report 2015. WHO Document Production Services, Geneva, Switzerland. 
2. Kementerian Kesehatan Indonesia. (2015). Profil Kesehatan Indonesia Tahun 2014. Kementerian Kesehatan Indonesia, Jakarta.

3. Enayati, A., Hemingway, J., \& Garner, P. (2010). Electronic Mosquito Repellent For Preventing Mosquito Bites And Malaria Infection (Review). The Cochrane Collaboration, John Wiley And Sons, Ltd, United Kingdom.

4. Shimoda, M. \& Honda. K. I. (2013). Insect Reaction To Light And Its Application To Pest Management. Appl Entomol Zool, 48, 413-421.

5. Burkett, D. A., Butler, J. F., \& Kline, D. L. (1998). Field Evaluation Of Colored Ligth-Emitting Diodes As Attractans For Woodland Mosquitoes And Other Diptera In North Central Florida. Journal of The American Mosquito Control Association, 14: 186-195.

6. Young, H. D. \& Freedman, R. A. (2003). Sears And Zemansky's : Fisika Universitas. Erlangga, Jakarta.
7. Andrizal. (2001). Studi Tentang Kontroler Elektronik Lampu Tabung Fluorescent. Institut Teknologi Bandung, Bandung.

8. Enny, I. (2003). Analisis Sistem Lampu TL Tanpa Filamen. Institut Teknologi Bandung, Bandung.

9. Mostavan, A. (2005). Teknik Pencahayaan. Departemen Teknik Fisika Institut Teknologi Bandung, Bandung.

10. Peitsch, D., Fietz, A., Hertel, H., Souza, J. Ventura, D. F., Menzel, R. (1992). The Spectral Input Systems Of Hymenopteran Insect And Their Receptor-Based Colour Vision. J Comp Physiol A, 170, 23-40.

11. Rueda, L. M. (2008). Global Diversity Of Mosquitoes (Insecta: Diptera: Culicidae). Hydrobiologia, 595, 477-487.

12. Syukur, A. (2012). Analisis Spasial Faktor Risiko Lingkungan Terhadap Kejadian Demam Berdarah Dengue (DBD) Di Kabupaten Sambas Propinsi Kalimantan Barat. Universitas Diponegoro, Semarang. 